\title{
Heterogeneous Microstructure and Distribution of Trace Elements in Coral Stylophora pistillata Nursed in the Phosphate Loading Berth Site in the Gulf of Aqaba
}

\author{
Ali Al-Sawalmih"1,2*, Jafar Megdadi1 \\ ${ }^{1}$ Marine Science Station, The University of Jordan \& Yarmouk University, Aqaba, Jordan \\ ${ }^{2}$ Department of Coastal Environment, Faculty of Marine Sciences, The University of Jordan, Aqaba, Jordan \\ Email: *a.sawalmih@ju.edu.jo
}

How to cite this paper: Al-Sawalmih, A. and Megdadi, J. (2016) Heterogeneous Microstructure and Distribution of Trace Elements in Coral Stylophora pistillata Nursed in the Phosphate Loading Berth Site in the Gulf of Aqaba. Natural Science, 8, 541-552. http://dx.doi.org/10.4236/ns.2016.812053

Received: May 3, 2016

Accepted: December 2, 2016

Published: December 5, 2016

Copyright $\odot 2016$ by authors and Scientific Research Publishing Inc. This work is licensed under the Creative Commons Attribution International License (CC BY 4.0).

http://creativecommons.org/licenses/by/4.0/

\begin{abstract}
Cultured Stylophora pistillata in Phosphate Loading Berth (PLB) sites in the Jordanian Gulf of Aqaba was investigated using Back-Scatter Scanning Electron (BSE) microscopy and Energy-Disperse X-ray (EDX) to determine trace elements and calcium concentrations' distribution within the micrometer scale. $\mathrm{Ca}, \mathrm{C}$, and $\mathrm{O}$ in addition to six trace elements $(\mathrm{Mg}, \mathrm{Sr}, \mathrm{S}, \mathrm{Cl}, \mathrm{Ni}$, and $\mathrm{Na}$ ) were mapped within the sample cross section. Samples from the PLB were as expected poorly mineralized as previously reported and showed mineralization heterogeneity in the micrometer length scale in the BSE image. In four selected positions within the cross sections, Ca concentration found to range between $0.44-1.80 \mathrm{wt} \%$ in low-mineralized regions and between 3.99 $4.66 \mathrm{wt} \%$ in mineralized regions. The average calcium concentrations were in accordance to previous study; about $10 \%$ of the Ca existed in the same coral species from other coastal sites in the Gulf of Aqaba. This could be attributed to the role of phosphate in inhibition of calcification and enhancement of photosynthesis. Amounts of trace elements in lower $\mathrm{Ca}$ concentration positions within the cross section were relatively very low except for chlorine, whereas positions with higher $\mathrm{Ca}$ contained amounts of $\mathrm{Na}$ and $\mathrm{Sr}$. This study reports remarkable heterogeneity in mineral distribution within the microstructure of the coral Stylophora pistillata under phosphate pollution stress.
\end{abstract}

\section{Keywords}

Phosphate, Coral, Gulf of Aqaba, Calcification, Stylophora pistillata, EDX, SEM 


\section{Introduction}

Terrestrial runoff into seawater leads to increasing loads of nutrients, sediments and pollutants discharged from the land like using and handling of fertilizers that contain phosphate [1] [2], which is considered to be a growing concern for most of the countries endowed with coral reefs [3] [4]. This is referred to high sensitivity of coral reef ecosystems to changes in the surrounding physicochemical environment [5].

Seawater contains trace elements in the form of $\mathrm{K}^{+}, \mathrm{Na}^{+}, \mathrm{Mg}^{2+}, \mathrm{Ca}^{2+}, \mathrm{Cl}^{-}$and $\mathrm{SO}_{4}^{2-}$ which have significant impacts on the formation and elemental composition of marine skeletons like corals [6]. Trace elements are secreted within the coral skeleton through either direct replacement of calcium (or carbonate) in coral aragonite structure for divalent ions [7] [8] [9], while non-divalent ions are trapped by the inclusion of detritus materials into skeletal pore spaces, uptake of organic materials, incorporation of metals into coral skeletons, or coral feeding [7] [8] [10] [11] [12]. The incorporation of trace elements in coral skeletal aragonite crystals provides chronological proxies for physiochemical changes in the surrounding environment [12] [13] [14].

Conventional loading systems of phosphates produced as a constituent of fertilizer result in very high levels of dust pollution in the surrounding coastal area, diffused and transported along the sea by winds [15]. Phosphate is an extremely dry and dusty material and its solubility in seawater is relatively high (20 - 56 micrograms per liter, depending on particle size) [16] [17]. In Aqaba seawater, phosphate dust was found to be soluble over the annual water temperature range and some algae may be able to solubilize particulate phosphate [18] [19].

Phosphate pollution has also been implicated as a contributor to the decline of reef ecosystems in the Gulf of Aqaba [20] [21] [22] [23]. Phosphate was reported to cause $36 \%$ inhibition of calcification in Stylophora pistillata at $2 \mathrm{ppm}$ concentrations in seawater, and stop it completely (99\%) at $100 \mathrm{ppm}$ [24]. It was found that phosphate is responsible for increasing the death rate of Stylophora pistillata coral [25] while other study reported tolerance of coral species Stylophora pistillata to phosphate [26]. AlSawalmih [27] in his studies on branches Stylophora pistillata that are nursed in the Phosphate Loading Berth (PLB) site, found very low calcium composition in the aragonitic skeleton, about $10 \%$ of it in the control samples. He also found that these microstructures of these branches suffered from alteration due to dominance of organic fibers in the skeleton.

The Stylophora pistillata is among the important common coral species in the Gulf of Aqaba as well as in the Red Sea and known to be the fastest of the scleractinian corals. It is also very suitable for research because it can also be sampled without causing major damage to the colony [28] [29].

In the present study, we investigate the heterogeneity of mineral content and trace elements in Stylophora pistillata corals in the Phosphate Loading Berth (PLB) site using Back-Scatter electron images and EDX techniques for elemental analysis. We also show the heterogeneous structure of the phases with different $\mathrm{Ca}$ concentrations in the micrometer scale within the skeleton. 


\section{Materials and Methods}

Small fragments of the model branching coral Stylophora pistillata were cultured in a mid-water floating nursery along the Jordanian coast of Gulf of Aqaba [30]. The fragments developed into small colonies to be used as bio-indicator for marine pollution in the selected sites.

Coral samples were collected from the nurseries in the Phosphate Loading Berth (PLB) site (Figure 1), which lies about $3 \mathrm{~km}$ south of Aqaba city and is the single port for loading and exporting phosphate ore in Jordan.

Coral samples were cut perpendicular to the skeletal growth using low speed diamond saw (BUEHLER Isomat, Germany) and cross section surfaces were further polished using ethyleneglycol lubricant to provide a flat surface that was coated with $\mathrm{Au}$ for the SEM imaging.

Field-Emission Scanning Electron Microscope (JEOL JSM-7500F) with an Oxford Instruments detector was used for performing the EDX analysis to measure the elemental content in the coral samples and their corresponding emission spectra, as well as acquiring Back-Scatter Electron (VSE) microscopy images for the cross section of the sample. EDX analysis usually involves the generation of an X-ray spectrum from the entire scan area of the SEM, which shows the counts of X-rays received and processed by the detector and the energy level of those counts. The EDX instrument software associates the energy level of the X-rays with the elements found in the scan area.

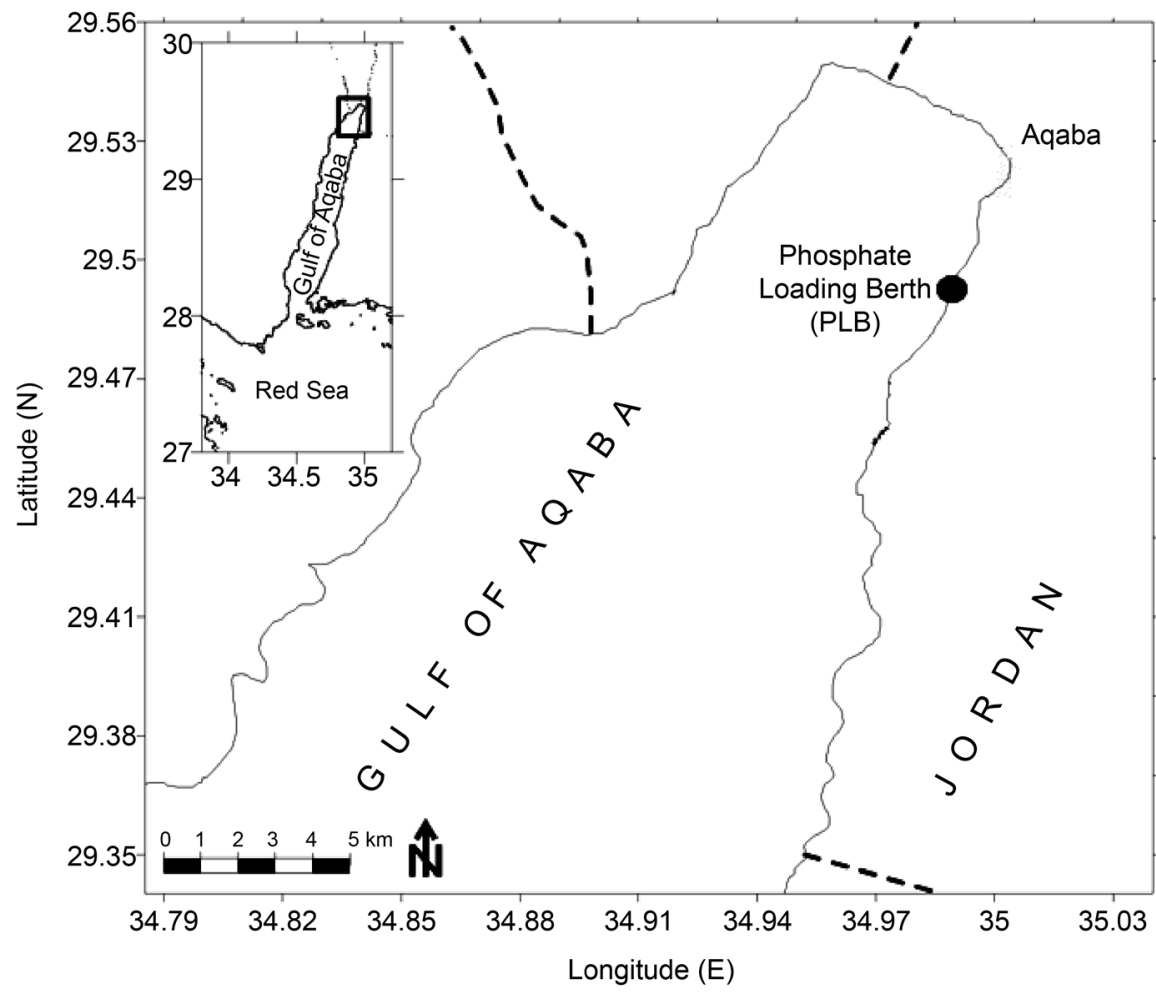

Figure 1. Map of the Gulf of Aqaba where the location of the Phosphate Loading Berth (PLB) is indicated. 


\section{Results and Discussion}

Figure 2 shows a Back-Scattering Electron (BSE) image for a polished surface of the coral sample. BSE can be used for rapid discrimination of phases in multiphase samples with high contrast of electron density, like organic and mineral phases, based on lessand more Ca concentrations.

Back-Scattered Scanning Electron Microscopy (BS-SEM) images of coral samples collected from the Phosphate Loading Berth (PLB) in the Jordanian Gulf of Aqaba (Figure 2) showed also that coral fragments from the phosphate pollution site is heterogeneous in the micrometer scale comprised of less-mineralized parts with very low calcium concentrations and mineralized parts with relatively higher calcium concentrations.

In Figure 2, the dark regions resemble the less-Ca phases and the bright ones indicates for the mineralized areas. This heterogeneous structure comes in accordance to the last study by Al-Sawalmih [27] on Stylophora pistillata coral samples from the phosphate pollution site, reporting dominance of organic/low-mineralized microstructure in SEM images and elemental analysis. This can be attributed to the role of phosphate in enhancement of coral zooxanthellae photosynthesis that is responsible for synthesis of organic matrix in the skeleton [31].

Four positions in the cross-section in the BSE image (Figure 2) were selected for elemental analysis using Energy-Dispersive X-rays (EDX); (1) and (2) in the lessmineralized "dark" region and (3) and (4) in the more mineralized "bright" region. The recorded EDX spectra from the positions 1-4 (Figure 3) were used by the instrument software to determine the weight percentage (wt\%) of Oxygen (O), Carbon (C) and Calcium (Ca) in addition to the trace elements: N, Mg, S, Cl, Ni and Sr. The full quantitative elemental analysis for the positions 1-4 are presented in Table 1.

In all locations, Ca concentrations were very low as expected and recorded in previous study on such coral in the same site [27] which was only $2.56 \mathrm{wt} \%$, which is around $12 \%$ of the average in the control sample (21.95 wt\%) but with a focus area

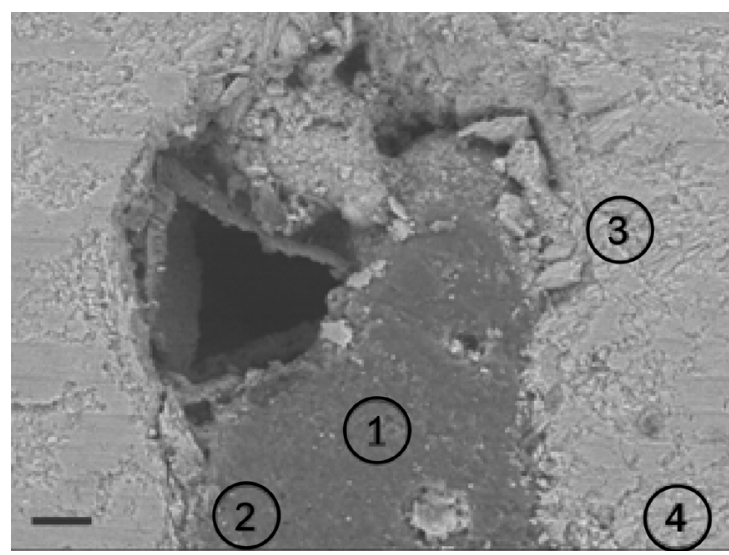

Figure 2. Back-Scatter Electron image of coral cross section. The four positions were selected for the EDX elemental analysis. The scale bar is 2 micrometer. 


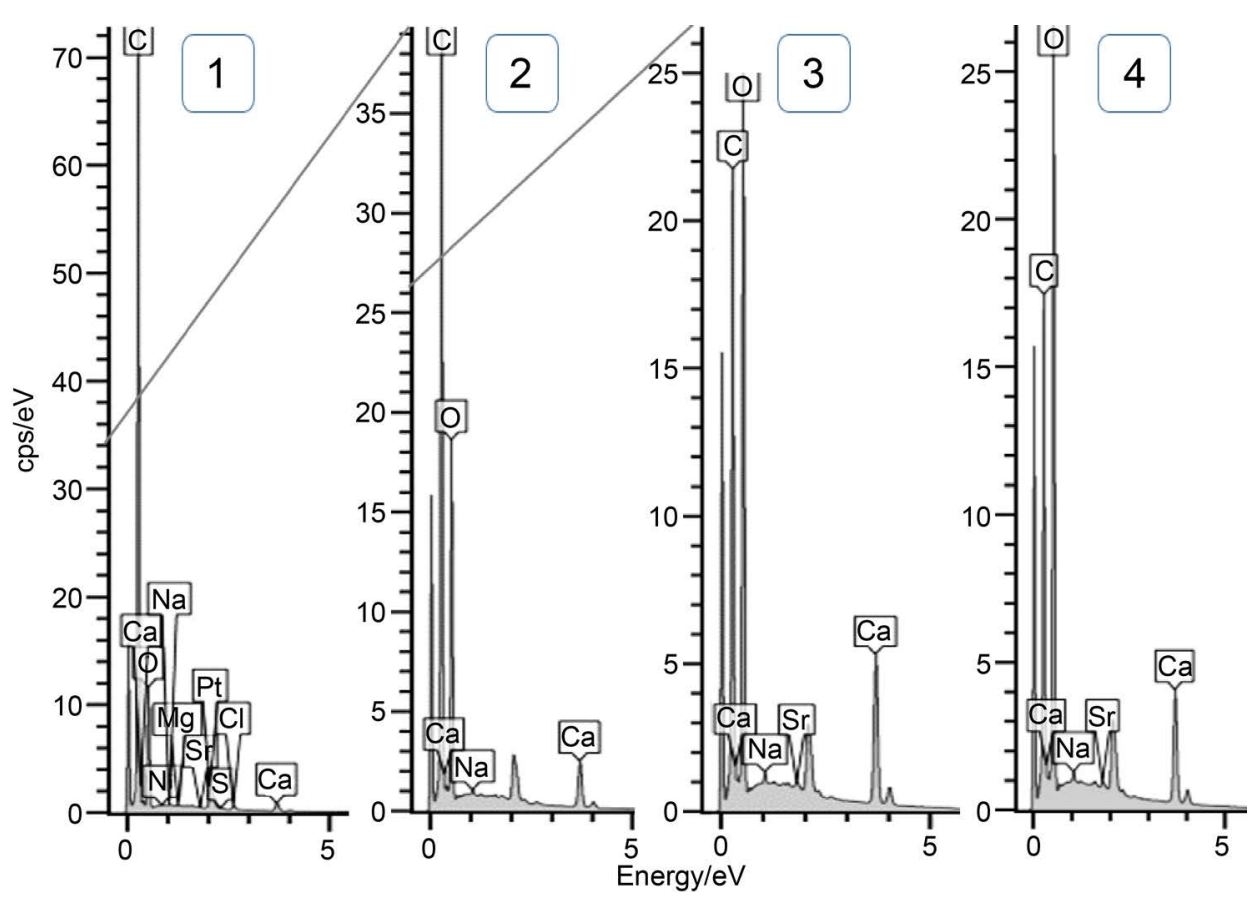

Figure 3. EDX spectra of the four selected positions for elemental analysis.

Table 1. Concentrations in wt\% of $\mathrm{C}, \mathrm{O}, \mathrm{Ca}$, and trace elements in the EDX scanned positions 1-4 in the coral cross section BSE image (Figure 2).

\begin{tabular}{ccccc}
\hline & 1 & 2 & 3 & 4 \\
\hline $\mathrm{C}$ & $74.72 \pm 0.11$ & $57.86 \pm 0.12$ & $41.85 \pm 0.14$ & $37.93 \pm 0.14$ \\
$\mathrm{O}$ & $24.67 \pm 0.11$ & $40.01 \pm 0.12$ & $52.85 \pm 0.14$ & $57.40 \pm 0.14$ \\
$\mathrm{Ca}$ & $0.44 \pm 0.01$ & $1.80 \pm 0.02$ & $4.66 \pm 0.03$ & $3.99 \pm 0.03$ \\
$\mathrm{Na}$ & $0.03 \pm 0.01$ & $0.14 \pm 0.02$ & $0.31 \pm 0.02$ & $0.30 \pm 0.02$ \\
$\mathrm{Mg}$ & --- & $0.04 \pm 0.01$ & $0.05 \pm 0.01$ & $0.04 \pm 0.02$ \\
$\mathrm{~S}$ & --- & --- & --- & --- \\
$\mathrm{Cl}$ & $0.14 \pm 0.01$ & $0.06 \pm 0.01$ & $0.05 \pm 0.01$ & $0.03 \pm 0.01$ \\
$\mathrm{Ni}$ & --- & $0.03 \pm 0.01$ & --- & $0.02 \pm 0.01$ \\
$\mathrm{Sr}$ & --- & $0.06 \pm 0.02$ & $0.24 \pm 0.03$ & $0.29 \pm 0.03$ \\
\hline
\end{tabular}

averages over the range of $100 \mathrm{~m}$. In our study, the focus area for the EDX analysis was in the range of $1 \mathrm{~m}$ in order to map the heterogeneity in trace element distribution within the skeleton microstructure.

In Figure 4, the spatial heterogeneity in $\mathrm{C}, \mathrm{O}$, and $\mathrm{Ca}$ concentrations are presented, showing in addition low $\mathrm{Ca}$ concentrations in the dark regions (1) and (2), higher $\mathrm{C}$ concentrations and lower $\mathrm{O}$ amounts. $\mathrm{C}$ percentage decreases with increase of mineral composition while $\mathrm{O}$ is decreasing. This can be also noticed in the elemental spectra in Figure 3. This is an obvious result; when organic material is dominating then the $\mathrm{C}$ concentrations becomes more. Quantitative correlation between concentrations of these 


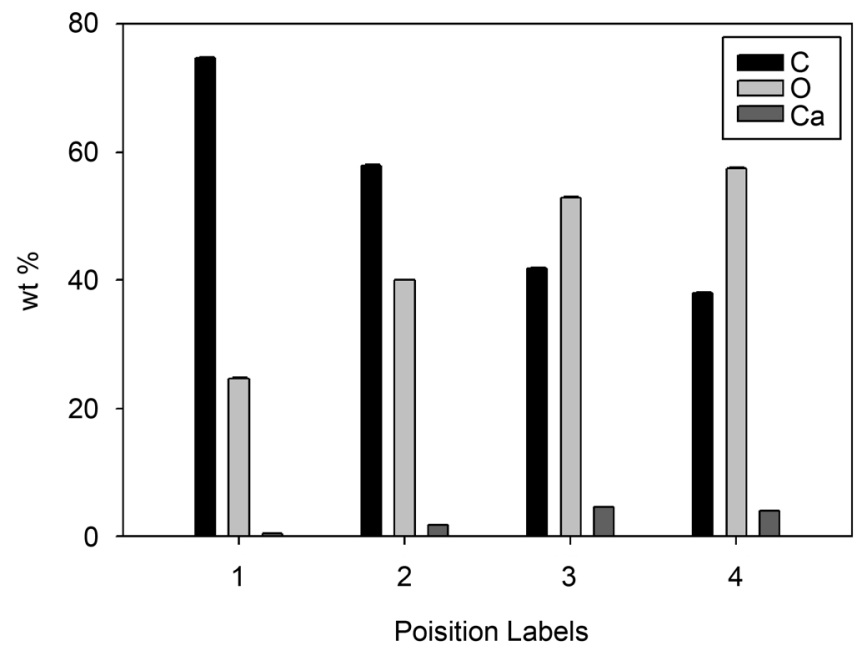

Figure 4. Bar chart representation of the concentrations in $\mathrm{wt} \%$ of $\mathrm{C}, \mathrm{O}$, and $\mathrm{Ca}$ in the EDX scanned positions 1-4 in the coral cross section BSE image (Figure 2).

elements needs to be further investigated based on expanded experimental work and literature survey. In the less-mineral region, position (2) has quite higher $\mathrm{Ca}$ than (1) because the last is located close to the less- and higher mineralized interface (Figure 2), which may give an indicator to the gradient behavior of $\mathrm{Ca}$ concentration through this boundary.

The amount of trace elements $(\mathrm{N}, \mathrm{Mg}, \mathrm{S}, \mathrm{Cl}, \mathrm{Ni}$, and $\mathrm{Sr}$ ) in the four scanned positions in the coral sample cross section (Figure 2) are shown in Figure 5. The EDX elemental analysis shows that the coral samples contain considerable amounts of trace elements (see Figure 1) which is strongly related to the chemistry of surrounding seawater during skeleton formation [10] [32] [33].

Except for Chlorine $(\mathrm{Cl})$, trace elements in the position 1 of the lowest calcium content were very low $(<0.1 \mathrm{wt} \%)$ so their amounts can't be considered due to possible uncertainty in their values. Trace elements concentrations can be reliably considered only in regions of high Ca concentrations.

The relatively high $\mathrm{Cl}$ concentration in position (1) which is 3 times more than it in other positions cannot be explained. Chlorine $(\mathrm{Cl})$ exist in coral skeletons (but not in the aragonitic structure), as potassium chloride or as sodium chloride phases and is considered to be toxic for corals [34]. The main source of excess of $\mathrm{Cl}$ in seawater is sewage treatment that during floods which may be mixed with seawater, in addition to biofouling treatment in industrial effluents [35].

In Figure 5, $\mathrm{Na}$ and $\mathrm{Sr}$ are the elements of the highest concentrations among other trace elements, which is typical for coral skeletons where $\mathrm{Na}$ and $\mathrm{Sr}$ are higher than any other trace element [36]. Moreover, it can be well noted from Figure 5 that Na concentrations are positively very well correlated with $\mathrm{Ca}$ concentrations. The average $\mathrm{Na} / \mathrm{Ca}$ ratio for all scanned positions is $0.072 \pm 0.005$. For Sr/Ca ratio, if we consider only the higher-mineralized part for accurate estimation, its averaged value become $0.062 \pm$ 


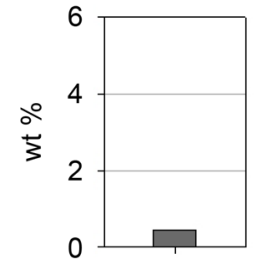

$\mathrm{Ca}$

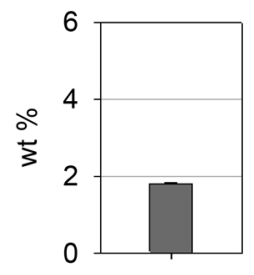

$\mathrm{Ca}$

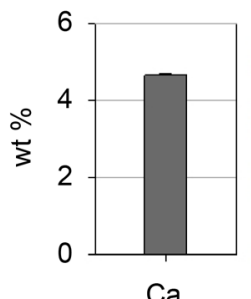

$\mathrm{Ca}$

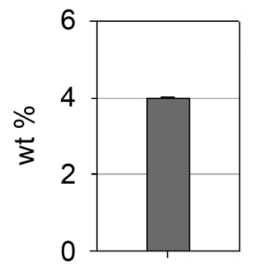

$\mathrm{Ca}$

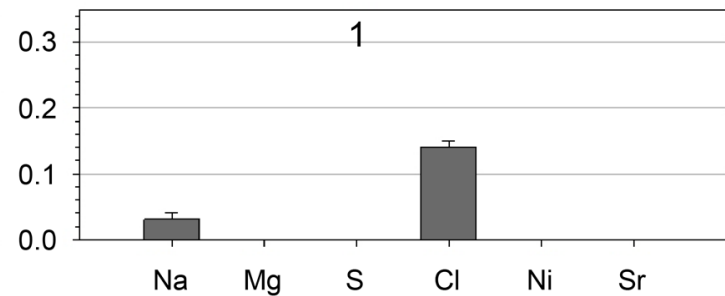

$\begin{array}{llllll}\mathrm{Na} & \mathrm{Mg} & \mathrm{S} & \mathrm{Cl} & \mathrm{Ni} & \mathrm{S} r\end{array}$
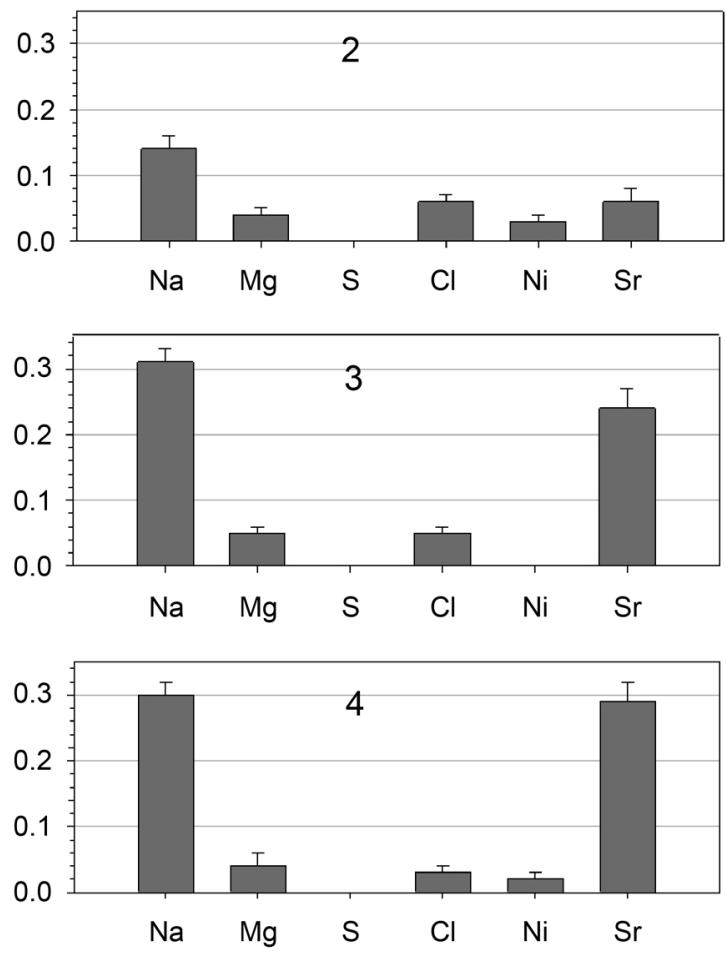

Figure 5. bar chart representation of the concentrations in wt $\%$ of $\mathrm{Ca}$, and trace elements in the EDX scanned positions 1-4 in the coral cross section BSE image (Figure 2).

0.015. However, the method used for this study is not optimal for calculating traceelement/Ca (mmole/mole) ratios.

Although $\mathrm{Na}$ is not a divalent cation (monovalent ion), i.e. it does not satisfy the electrostatic valence requirements of the Ca position in the aragonite lattice, but being the second most abundant ion in seawater [37], in addition to the similarity of its ionic radius, $\mathrm{Na}$ transfers rapidly from sea water into the crystallizing skeletal material [38]. The charge imbalances resulting from the incorporation of $\mathrm{Na}^{+}$into aragonite lattices is compensated by lattice defects and distortions such as vacancy sites and interstitial ions that occur at higher density at the center of calcification [36] [39].

Strontium ( $\mathrm{Sr}$ ) ion is a divalent cation as magnesium $(\mathrm{Mg})$, which can be secreted within the coral skeleton through direct replacement of calcium (or carbonate) in coral aragonite structure [7] [8] [9]. Sr is preferentially incorporated into the organically precipitated aragonitic skeletal material although having greater ionic radius than $\mathrm{Ca}$ [40]. $\mathrm{Sr}$ levels in the coral aragonitic skeleton has long been recognized as an indicator of 
seawater temperature at the time of coral growth, but anthropogenic pollution in seawater may effect on the temperature record [41].

$\mathrm{Mg}$ is generally found in much lower concentrations in aragonitic skeletons due to its smaller ionic radius than $\mathrm{Ca}$ [42], although being the third most abundant ion in seawater, behind sodium $(\mathrm{Na})$ and chloride $(\mathrm{Cl})[6]$.

Due to its inhibition of calcification, high levels of phosphate are inversely associated with decreasing concentrations of strontium in the corals [43]. Nevertheless, morphological alteration of the coral skeleton due increased levels of phosphate suggests also that strontium may provide an excellent indicator of environmental stress related to anthropogenic-induced elevated nutrient levels [41].

Sulphur (S) was not detected in our sample. It is the forth abundant ion in seawater (as sulfate $\mathrm{SO}_{4}^{2-}$ ) following close behind $\mathrm{Mg}$ [37]. It exists in coral skeletons as occupying specific sites in the crystal lattice of marine aragonites [44] [45].

Nickel $(\mathrm{Ni})$ concentrations in the four scanned positions were almost not detected. It is weakly incorporated into the aragonite skeleton relative to calcium concentrations due to structural incompatibility [46]. Although $\mathrm{Ni}$ is vital for the function of many organisms, concentrations in some areas from both anthropogenic release and natural sources might increase its concentrations to toxic levels to living organisms [47] [48] [49].

The low calcium in corals that are stressed by phosphate dust pollution, is due to the enrichment of phosphate as nutrient in seawater which cause inhibition of calcification in corals and coralline algae as well [25] [50]. It was reported that phosphate in seawater decrease calcification in the corals Pocillopora damicornis [51], through increasing eutrophication which effects on survival and stability of reef communities by disrupting normal carbon cycle functions [52] [53] [54]. However, the mechanisms by which dissolved inorganic nutrients like phosphates can disturb corals are subject to controversial debate [55].

The environmental impacts of the deposited phosphate dust on marine ecosystem include not only siltation of the coral reef and depression of coral growth (Hawkins et al., 1991) but also increasing suspended solids and water turbidity, reduction of water clarity and light penetration [56]. Phosphate dust also has physical effects in reducing the light intensity and increasing sedimentation, both of which have been shown to have deleterious effects on reefs [57]. Reduced light, excess phosphate and sedimentation were found to be responsible for reduced calcification and increased mortality of corals [25].

\section{Conclusion}

Distribution of calcium in different very low concentrations was found in skeleton of corals that are exposed to phosphate dust and heterogeneous in the micrometer scale. This can be attributed to the well-known inhibition process of calcification by increase of phosphate concentrations at the time that the corals were formed. Dominating trace elements were only $\mathrm{Na}$ and $\mathrm{Sr}$, which is typical for coral skeleton constituent. Chlorine 
was found to be higher in the lowest-calcium concentrations than other regions. Further elemental analysis and microstructure studies could be conducted on other coral species and several skeletal organisms that live in the Phosphate Terminal coastal site in order to find out their response to phosphate pollution. Moreover, trace element/Ca ratios should be considered in future similar studies using suitable investigation techniques for complete analysis.

\section{Acknowledgements}

The authors are indebted to Prof. Fuad Al-Horani for providing the coral samples used for this study and to Prof. Peter Fratzl for giving the chance to use the SEM laboratory at the Max-Planck Institute for Colloids and Interfaces (MPIKG). Many thanks to Susann Weichold and Heike Runge of the SEM lab Germany for their support and help during the measurements, also we are thankful to the divers Ali Al-Njadat and Omar Al-Momany for collecting the coral samples used in this study.

\section{References}

[1] Smith, S.V., et al. (2003) Humans, Hydrology, and the Distribution of Inorganic Nutrient Loading to the Ocean. Bioscience, 53, 235-245. https://doi.org/10.1641/0006-3568(2003)053[0235:HHATDO]2.0.CO;2

[2] Tilman, D., et al. (2001) Forecasting Agriculturally Driven Global Environmental Change. Science, 292, 281-284. https://doi.org/10.1126/science.1057544

[3] Bryant, D.G., et al. (1998) Reefs at Risk: A Map-Based Indicator of Threats to the World's Coral Reefs. World Resources Institute, Washington DC.

[4] Spalding, M., Ravilious, C. and Green, E.P. (2001) World Atlas of Coral Reefs. University of California Press, Berkeley.

[5] Johannes, R.E. (1972) Coral Reefs and Pollution. In: Ruivo M., Ed., Marine Pollution and Sea Life, Fishing News (Books), London, 364-374.

[6] Martin, D.F. (1972) Marine Chemistry. 2nd Edition, M. Dekker, New York.

[7] Correge, T. (2006) Sea Surface Temperature and Salinity Reconstruction from Coral Geochemical Tracers. Palaeogeography Palaeoclimatology Palaeoecology, 232, 408-428. https://doi.org/10.1016/j.palaeo.2005.10.014

[8] Flor, T.H. and Moore, W.S. (1977) Radium/Calcium and Uranium/Calcium Determinations for Western Atlantic Reef Corals. 3rd International Coral Reef Symposium, 2, 555561.

[9] Weber, J.N. (1973) Incorporation of Strontium into Reef Coral Skeletal Carbonate. Geochimica et Cosmochimica Acta, 37, 2173-2190.

https://doi.org/10.1016/0016-7037(73)90015-X

[10] Hanna, R.G. and Muir, G.L. (1990) Red-Sea Corals as Biomonitors of Trace-Metal Pollution. Environmental Monitoring and Assessment, 14, 211-222. https://doi.org/10.1007/BF00677917

[11] Howard, L.S. and Brown, B.E. (1986) Metals in Tissues and Skeleton of Fungia-Fungites from Phuket, Thailand. Marine Pollution Bulletin, 17, 569-570. https://doi.org/10.1016/0025-326X(86)90573-4

[12] Smith, S.V., Buddemeier, R.W., Redalje, R.C. and Houck, J.E. (1979) Strontium-Calcium 
Thermometry in Coral Skeletons. Science, 204, 404-407.

https://doi.org/10.1126/science.204.4391.404

[13] Al-Rousan, S., Al-Shloul, R., Al-Horani, F. and Abu-Hilal, A. (2012) Heavy Metals Signature of Human Activities Recorded in Coral Skeletons along the Jordanian Coast of the Gulf of Aqaba, Red Sea. Environmental Earth Sciences, 67, 2003-2013. https://doi.org/10.1007/s12665-012-1640-0

[14] Stanley, S.M. and Hardie, L.A. (1998) Secular Oscillations in the Carbonate Mineralogy of Reef-Building and Sediment-Producing Organisms Driven by Tectonically Forced Shifts in Seawater Chemistry. Palaeogeography, Palaeoclimatology, Palaeoecology, 144, 3-19. https://doi.org/10.1016/S0031-0182(98)00109-6

[15] Sandler, D. (1993) Protecting the Gulf of Aqaba: A Regional Environmental Challenge, Environmental Law Institute, Washington DC, $512 \mathrm{p}$.

[16] Bemert, G. and Ormond, R. (1981) Red Sea Coral Reefs. Kegan Paul International, London, $192 \mathrm{p}$.

[17] Freemantle, M.H., Hulings, N., Mulqi, M. and Watton, E.C. (1978) Calcium and Phosphate in Jordan Gulf of Aqaba. Marine Pollution Bulletin, 9, 79-80. https://doi.org/10.1016/0025-326X(78)90454-X

[18] Grobler, D.C. and Davies, E. (1979) Availability of Sediment Phosphate to Algae. Water $S A$, 5, 114-122.

[19] McColl, R.H.S. (1975) Availability of Soil and Sediment Phosphorus to a Planktonic Alga. New Zealand Journal of Marine and Freshwater Research, 9, 169-182. https://doi.org/10.1080/00288330.1975.9515557

[20] Fishelson, L. (1973) Ecology of Coral Reefs in Gulf of Aqaba (Red-Sea) Influenced by Pollution. Oecologia, 12, 55-67. https://doi.org/10.1007/BF00345470

[21] Fishelson, L. (1977) Stability and Instability of Marine Ecosystems, Illustrated by Examples from Red-Sea. Helgolander Wissenschaftliche Meeresuntersuchungen, 30, 18-29. https://doi.org/10.1007/BF02207822

[22] Loya, Y. (1975) Possible Effects of Water-Pollution on Community Structure of Red-Sea Corals. Marine Biology, 29, 177-185. https://doi.org/10.1007/BF00388987

[23] Al-Sawalmih, A., et al. (2016) Elemental Analysis of the Branched Coral Stylophora pistillata Nursed along the Jordanian Coast of Gulf of Aqaba. Marine Pollution Bulletin, In Preparation.

[24] Yamashiro, H. (1995) The Effects of Hebp, an Inhibitor of Mineral Deposition, upon Photosynthesis and Calcification in the Scleractinian Coral, Stylophora pistillata. Journal of Experimental Marine Biology and Ecology, 191, 57-63. https://doi.org/10.1016/0022-0981(95)00045-S

[25] Walker, D.I. and Ormond, R.F.G. (1982) Coral Death from Sewage and Phosphate Pollution at Aqaba, Red-Sea. Marine Pollution Bulletin, 13, 21-25. https://doi.org/10.1016/0025-326X(82)90492-1

[26] Loya, Y. (1976) Red-Sea Coral Stylophora pistillata Is a R-Strategist. Nature, 259, 478-480. https://doi.org/10.1038/259478a0

[27] Al-Sawalmih, A. (2016) Calcium Composition and Microstructure of Coral Stylophora pistillata under Phosphate Pollution Stress in the Gulf of Aqaba. Natural Science, 8, 89-95. https://doi.org/10.4236/ns.2016.83012

[28] Loya, Y. (1972) Community Structure and Species Diversity of Hermatypic Corals at Eilat, Red Sea. Marine Biology, 13, 100-123. https://doi.org/10.1007/BF00366561

[29] Loya, Y. and Slobodkin, L.B. (1971) The Coral Reefs of Eilat (Gulf of Eilat, Red Sea). In: 
Yonge, M. and Stoddart, D.R., Eds., Regional Variation of Indian Ocean Coral Reefs, Academic Press, New York, 117-139.

[30] Al-Horani, F. (2013) Sustainable Resources of Corals for the Restoration of Damaged Coral Reefs in the Gulf of Aqaba, Red Sea. Life Science Journal, 10, 352-360.

[31] Jones, O.A. and Endean, R. (1973) Biology and Geology of Coral Reefs. Academic Press, New York.

[32] Esslemont, G. (2000) Heavy Metals in Seawater, Marine Sediments and Corals from the Townsville Section, Great Barrier Reef Marine Park, Queensland. Marine Chemistry, 71, 215-231. https://doi.org/10.1016/S0304-4203(00)00050-5

[33] Ramos, A.A., Inoue, Y. and Ohde, S. (2004) Metal Contents in Porites Corals: Anthropogenic Input of River Run-Off into a Coral Reef from an Urbanized Area, Okinawa. Marine Pollution Bulletin, 48, 281-294. https://doi.org/10.1016/j.marpolbul.2003.08.003

[34] Johannes, R.E. (1975) Chapter 2: Pollution and Degradation of Coral Reef Communities. In: Wood, E.J.F. and Johannes, R.E., Eds., Elsevier Oceanography Series, Elsevier, Amsterdam, 13-51. https://doi.org/10.1016/s0422-9894(08)71107-3

[35] Wood, E.J.F. and Johannes, R.E. (1975) Tropical Marine pollution. Elsevier Oceanography Series 12, Elsevier, Amsterdam, 192 p.

[36] Mitsuguchi, T., Uchida, T. and Matsumoto, E. (2010) Na/Ca Variability in Coral Skeletons. Geochemical Journal, 44, 261-273. https://doi.org/10.2343/geochemj.1.0067

[37] Turekian, K.K. (1968) Oceans. Foundations of Earth Science Series, Prentice-Hall, Englewood, $120 \mathrm{p}$.

[38] Harriss, R.C. and Almy, J.C.C. (1964) A Preliminary Investigation into the Incorporation and Distribution of Minor Elements in the Skeletal Material of Scleractinian Corals. Bulletin of Marine Science, 14, 418-423.

[39] White, A.F. (1977) Sodium and Potassium Coprecipitation in Aragonite. Geochimica et Cosmochimica Acta, 41, 613-625. https://doi.org/10.1016/0016-7037(77)90301-5

[40] Wray, J.L. and Daniels, F. (1957) Precipitation of Calcite and Aragonite. Journal of the American Chemical Society, 79, 2031-2034. https://doi.org/10.1021/ja01566a001

[41] Rasmussen, C.E. (1988) The Use of Strontium as an Indicator of Anthropogenically Altered Environmental Parameters. 6th International Coral Reef Symposium Executive Committee, Townsville, 8-12 August 1988, 325-339.

[42] Chave, K.E. (1954) Aspects of the Biogeochemistry of Magnesium 1. Calcareous Marine Organisms. Journal of Geology, 62, 266-283. https://doi.org/10.1086/626162

[43] Senesi, N., Polemio, M. and Lorusso, L. (1983) Evaluation of Barium, Rubidium and Strontium Contents in Commercial Fertilizers. Fertilizer Research, 4, 135-144. https://doi.org/10.1007/BF01053250

[44] Barmatthews, M., Wasserburg, G.J. and Chen, J.H. (1993) Diagenesis of Fossil Coral Skeletons: Correlation between Trace-Elements, Textures, and U-234/U-238. Geochimica et Cosmochimica Acta, 57, 257-276. https://doi.org/10.1016/0016-7037(93)90429-Z

[45] Vielzeuf, D., et al. (2013) Distribution of Sulphur and Magnesium in the Red Coral. Chemical Geology, 355, 13-27. https://doi.org/10.1016/j.chemgeo.2013.07.008

[46] Rasmussen, C.E., Cuff, C. and Hopley, D. (1992) Evidence of Anthropogenic Disturbances Retained in the Skeleton of Massive Corals from Australia's Great Barrier Reef. 7 th International Coral Reef Symposium, Guam, 22-27 June 1992.

[47] Diagomanolin, V., Farhanga, M, Ghazi-Khansaria, M. and Jafarzadeh, N. (2004) Heavy Metals (Ni, Cr, Cu) in the Karoon Waterway River, Iran. Toxicology Letters, 151, 63-68. 
https://doi.org/10.1016/j.toxlet.2004.02.018

[48] Haber, L.T., et al. (2000) Hazard Identification and Dose Response of Inhaled NickelSoluble Salts. Regulatory Toxicology and Pharmacology, 31, 210-230.

https://doi.org/10.1006/rtph.2000.1377

[49] Scott-Fordsmand, J.J. (1997) Toxicity of Nickel to Soil Organisms in Denmark. In: Ware, G.W., Nigg, H.N. and Bevenue, A., Eds., Reviews of Environmental Contamination and Toxicology: Continuation of Residue Reviews, Springer, New York, 1-34. https://doi.org/10.1007/978-1-4612-2264-4_1

[50] Simkiss, K. (1964) Phosphates as Crystal Poisons of Calcification. Biological Reviews of the Cambridge Philosophical Society, 39, 487-504. https://doi.org/10.1111/j.1469-185X.1964.tb01166.x

[51] Lamberts, A.E. (1974) Measurement of Alizarin Deposited by Coral. In: Cameron, A.M. and Cambell, B.M., Eds., The Second International Coral, The Great Barrier Reef Waters, Department of Zoology, University of Hawaii, Honolulu, 241-244.

[52] Sawall, Y., Teichberg, M.C., Seemann, J., Litaay, M., Jompa, J. and Richter, C. (2011) Nutritional Status and Metabolism of the Coral Stylophora subseriata along a Eutrophication Gradient in Spermonde Archipelago (Indonesia). Coral Reefs, 30, 841-853. https://doi.org/10.1007/s00338-011-0764-0

[53] Godinot, C., Ferrier-Pagès, C., Montagna, P. and Grover, R. (2011) Tissue and Skeletal Changes in the Scleractinian Coral Stylophora pistillata Esper 1797 under Phosphate Enrichment. Journal of Experimental Marine Biology and Ecology, 409, 200-207. https://doi.org/10.1016/j.jembe.2011.08.022

[54] Dunn, J.G., Sammarco, P.W. and LaFleur Jr., G. (2012) Effects of Phosphate on Growth and Skeletal Density in the Scleractinian Coral Acropora muricata: A Controlled Experimental Approach. Journal of Experimental Marine Biology and Ecology, 411, 34-44. https://doi.org/10.1016/j.jembe.2011.10.013

[55] D’Angelo, C. and Wiedenmann, J. (2014) Impacts of Nutrient Enrichment on Coral Reefs: New Perspectives and Implications for Coastal Management and Reef Survival. Current Opinion in Environmental Sustainability, 7, 82-93. https://doi.org/10.1016/j.cosust.2013.11.029

[56] Hashwa, F. (1980) The Phosphate Pollution in the Gulf of Aqaba. Khartoum.

[57] Dodge, R.E. and Vaisnys, J.R. (1977) Coral Populations and Growth-Patterns: Responses to Sedimentation and Turbidity Associated with Dredging. Journal of Marine Research, 35, 715-730. 
Submit or recommend next manuscript to SCIRP and we will provide best service for you:

Accepting pre-submission inquiries through Email, Facebook, LinkedIn, Twitter, etc. A wide selection of journals (inclusive of 9 subjects, more than 200 journals)

Providing 24-hour high-quality service

User-friendly online submission system

Fair and swift peer-review system

Efficient typesetting and proofreading procedure

Display of the result of downloads and visits, as well as the number of cited articles

Maximum dissemination of your research work

Submit your manuscript at: http://papersubmission.scirp.org/

Or contact ns@scirp.org 